\title{
CULTURE ON TRIAL: GREMER CHAN REYES'S MEN AT SEA
}

\author{
Hope Sabanpan-Yu \\ Cebuano Studies Center, University of San Carlos \\ hsyu@shaw.ca
}

\begin{abstract}
Translation has emerged as a relevant medium through which countries can be familiar with and understand each other, and people can gain access to knowledge which would not have been available in any other way. Translation works like a mirror where one can reflect upon the self as well as use it as a window to look through other cultures. This paper refers to this contextual frame as it attempts to introduce a Cebuano text, Gremer Chan Reyes' Men at Sea, to English speakers.
\end{abstract}

\section{Keywords}

Foreignization, domestication, mirroring, cultural political practice, difference

\section{About the Author}

Hope Sabanpan-Yu is director of the University of San Carlos Cebuano Studies Center and a professor of comparative literature at the Department of Languages and Literature. She teaches both undergraduate and graduate courses in literature, creative non-fiction, theory and criticism. She has translated and edited several Cebuano works into English which have been published by the National Commission for Culture and the Arts and by the USC Press. 
AS A BASIC MEANS OF COMMUNICATION, translation plays a key role in our lives. It is through translation that people from one culture can articulate their opinions to people from another; more so, where there are global investments and interests scattered worldwide and the contact is enabled only through translation. In fact, any translation has a point and aim that determines its significance. In The Scandals of Translation, Lawrence Venuti writes that translations "are designed for many reasons, literary and commercial, pedagogical and technical, propagandistic and diplomatic" (3). These points may intersect at some moments but the basic reason for the translation often controls the situation.

Translation tends to address a particular message in the fields of politics and business and when the message is understood, the translation has been successful. Oftentimes, the translation of the message is direct and simple, particularly when the speaker understands the target culture. This, however, varies when one intends to preserve the beauty of the source text. In an aesthetic translation, much of the work will depend on the linguistic and stylistic relations between the source and target languages in question and the method of translation. A translator can either "domesticate" the foreign text, where the text created would seem as if it were written originally in the target language or "foreignize" the source text which maintains the cultural differences as well as the strangeness of the text (Scandals 309).

The method I chose in translating Gremer Chan Reyes's stories in the collection Men at Sea and Other Stories is "foreignization." The method, as proposed by Venuti in The Translator's Invisibility: A History of Translation, gives "information about the source-language text-its discursive structures, its themes and ideas" (312). This method provides me the opportunity to present Cebuano culture to Western readers by adhering as closely as possible to the source text but recreating a text in the target language where discrete features and cultural differences of the source text are maintained and showcased. Venuti calls for translators to insist on "foreignizing translation" in order to open "spaces for new ideas, concepts of alterity, and literary innovation" (Invisibility 18). He argues against textual fluency and advocates a "resistant" translation which makes the reader constantly aware of reading a translation: a text informed by the translator's choices. For instance, here is a passage from the story "The Child and the Fearsome Crab" where the foreign aspect is preserved:

The toddy gatherer took the container he had clipped to the asyutis and poured it into his hungot. Then he gazed toward the hut at the foot of the mountain. (127)

The italicized words reveal that this passage depicts specific Cebuano experience. But what about the Western reader, reading in English? To address this, I wrote an introduction for each story which includes details that frame the entire story in its 
cultural context. I also indicated footnotes explaining the Cebuano words which are italicized in the translation. Had I chosen a "domesticated" version, the passage would read:

The toddy gatherer took the container he had clipped to the reddish-brown mixture and poured it into his bowl made out of three-quarters of a coconut shell. Then he gazed toward the hut at the foot of the mountain.

This latter translation is sure to be misleading as the reader might think of different reddish-brown mixtures. But it is an intricate matter to convert a text from one culture into another without some kind of domestication, because linguistically and conceptually no two concepts are the same.

In the business of translation, not all concepts that are expressed in a language are the same as those that are expressed in another. In "No Two Snowflakes Are Alike," Gregory Rabassa gives the example of the "dog" -being a vile creature among Muslims, whereas for others, especially Americans, dogs are held with love and affection (2). Another example is the island in Cebuano being feminine. In my translation the source connotation in "The Fish of the Flower of Talikod" reads:

Dodo, Matanhag is an enchantress. The moment you fall in love and she will love you in return, you'll never get away from her embrace. (114)

Because of the fact that I chose "foreignization" as the method to use while translating Gremer Chan Reyes's Men at Sea, I found that I was always limited by the language boundaries and what Hugo Friedrich describes as "the pressing necessity to remain, as closely as possible, faithful to the original text" (11). So when sentences were long, I kept them long, also with Cebuano words and the texture of foreignness. Where the language of the translated text tended to be less poetic, I had to resort to dictionaries and thesauruses. I had to look for an equivalent in a Cebuano-English dictionary and then check its usage with an English dictionary. Foreignizing techniques include the use of transcribed foreign words, literal translations of sayings and proverbs, and para-textual devices such as footnotes.

In the Cebuano text, the writer shifts from one tense to another without warning and I retained these shifts in tense as part of the "foreignization" method. Tense shifts such as those in the source text may be acceptable since readers do not focus much on the tense; rather they concentrate on the idea behind the text. Moreover, the collection itself is replete with colloquial language which is known for frequent tense shifts. Another reason for this occurrence is when something unexpected happens, when one is supposed to be lively but is tired, so the shift is a device of relaxation. Yet, another possible reason might be attributed to the author's desire to show the indifference of time for the characters in the story. The present is the same as the past. 
There are restrictions for what is considered acceptable in translation which vary according to the ideologies and values a society has. Translation often places the many aspects of a culture on trial, like the ideologies and beliefs of a society. It critiques all these aspects whether by affirming or contradicting specific limits and institutional policies in the culture in question.

The very choice of a foreign text for translation can also signify its foreignness by challenging domestic canons for foreign literature and domestic stereotypes for foreign cultures. (Scandals 81)

The translation I have endeavored to do falls within this context.

In addition, translation directs the target reader to experience a process of "mirroring" (Scandals 77). The questions are: What is the benefit of reading a translation? With whom does the reader identify in a translation? Venuti posits that translation has a "cultural political practice" in constructing national identities. In this endeavor, my wish is that this translation will counteract the stereotypes many English readers have of Filipino society. Through translation, people can create an atmosphere of respect and deeper understanding.

The end goal of my translation is cognitive-the target reader will be able to read and learn about Philippine culture, about things that are universal in cultures, about similarities, and about differences among cultures in discussion. As a translator, I have learned many things. Hans Erich Nossack has said this better:

Translation is practical training for every writer in the use of available material; he learns to recognize the riches of his own language and to make use of its flexibility. (212)

Despite everything that has already been mentioned so far, I believe Venuti is correct with respect to what translation means to many, in practical terms:

Translation is stigmatized as a form of writing, discouraged by copyright law, depreciated by the academy, exploited by publishers and corporations, governments and religious organizations. (Scandals 1 )

Although translation is a relevant means for communication between cultures, countries, and peoples, most of us underestimate its significance in our world. As a field of cultural confrontation, critics and theorists know the important role of translation in communicating among people and in the understanding of diverse cultures. It can also be used to critique the past and correct false ideas. As long as there are distinctions among cultures, the issue of difference becomes the focus as a key topic. 
There might be no noticeable threat posed by difference if through translation the meaning or writing were in the same language but what guarantee is there that no such danger will occur when there are confrontations between different linguistic and cultural traditions?

Edward Said notes in Orientalism that "difference" was a way for the West to control the East. In Between Languages and Cultures: Translation and CrossCultural Texts, Said also considers why American publishers refuse to do literary translations from Arabic and how published translations do not get picked up by researchers as these do not repeat "the usual clichés" in the West (99). When there is a conflict between two cultures, the exploitation of one culture by another becomes a possible consequence. For that reason, "difference" may be used against one of those cultures. However, exploitation varies and changes in type and degree from one time to another and from one place to another.

"Differences" are often received or perceived variously and people react diversely to these, through generations. Moreover, cultures would not be recognized without divergence; it is through difference that an identity can be recognized. Thus, translation helps keep distinctions that, also, keep cultures recognized, understood and respected by others. If people want to understand each other and enrich their cultures, they need to know about being "different."

Venuti has a different take on "differences." In The Translator's Invisibility: A History of Translation, he makes a case for maintaining cultural differences while translating. In The Scandals of Translation: Towards an Ethics of Difference, however, he cautions that a translation's ethics of difference may result in dominance or ethnocentrism (83). When there is a serious attempt to negotiate and understand cultural differences, we can learn from and respect other cultures and even enrich our own instead of perceiving them as obstacles between cultures during translation.

Many Filipinos blame the West for stereotyping them, but they hardly take the responsibility for breaking down those stereotypes. A culture should be introduced by a local of that culture. Outsiders cannot present a culture the way a native can. Outsiders often appraise other cultures on the basis of their own, and their ideological values. Such evaluation, then, can lead to inventing enduring myths, widespread stereotypes and negative attitudes toward others. A local, on the other hand, tends to present the culture as its own people view it. A local's essential goal is to let other people understand and respect his/her culture the way s/he does.

As a native Cebuano speaker, I have worked on translating Cebuano works. Of course, it is my goal that my translations will change the stereotype other cultures have of Filipinos, especially as myths are not restricted to films but can also appear on television, books, and magazines. For instance, Filipinos are often stereotyped as nannies and domestic helpers in the West. My translations will introduce other types of workers in the Philippines and show how those people are living in a way that is different from what people in the West think of the Filipinos. Through my 
translations, I also wish to show more about life in a country that many Westerners know little about.

Gremer Chan Reyes's collection of short stories, Men at Sea and Other Stories offers complex readings of Cebuano culture that complicate ideas of class and gender in the political and domestic world of 21st century Cebu. It offers the non-Cebuano speaking reader the role of a visitor in this foreign setting, obliged to translate words and cope with cognitive gaps. The tensions inherent in the experience of reading a "different" narrative call on the translator to recognize and respect these effects and to decide to what extent to duplicate or foreignize them in the translation. To find answers to this fundamental dilemma of translation, I spoke with the author and received comments from him.

\section{Considering Language and Culture}

Knowing that Reyes lived in San Remigio, about three hours from my home in Cebu City, I contacted him in August of 2007. We talked about the inspiration, characterization, themes, audiences and purposes of his stories. Reyes affirms that he wrote the stories out of a desire to record and express Cebuano experience from a Cebuano perspective. I translated Men at Sea and Other Stories to represent his voice and perspective to English readers, and to share what I felt to be a rare and worthwhile message with others who would otherwise never hear this voice or see this perspective. Nevertheless, I realized that our worldviews were significantly different. He had written and I was translating the text for reasons that were similar but not identical. I sensed that no matter how faithful I intended to be with the original text, I would be writing for an audience whose cultural knowledge of the narrative's context differed greatly from that of Reyes' original intended audience.

Gremer Chan Reyes admits that he wrote the stories in Cebuano instead of English for various reasons. He wrote for a generation of young Cebuanos so that they may learn of Cebuano ways and recent history as Cebuanos tell and write it rather than through the bias of a colonial ideology. He also wrote for people of other cultures to present a Cebuano's point of view. He wrote in Cebuano because he felt he could use Cebuano more aggressively and express himself more freely in his own tongue, for an audience to read Cebuano.

In Men at Sea and Other Stories, Reyes describes traditional ways of the community, landscape, and rules of behavior. These passages of ethnographic description appeal to English-speaking audiences as well as Cebuano readers, though each set of readers is likely to receive them differently. For example,

"Bantay-panggunit!. . ." Labihan ka kusog ang nagsingabot nga alimpulos. Gidagit ang tubig sa dagat ug mapungtanong gilapdos dinha sa iyang agianan. Gikusokuso ang ilang sakayan ug gialsa ug gibundak nga malubong sa tubig sa dagat. ("Binuhat sa Lawod" 35) 
"Watch it! . . . Hold on!" Before them, a huge whirlpool was stirring. It was so strong that the water would pulverize whatever got sucked in its way. He felt like the boat was being scrubbed from the ocean like a dirty spot on some laundry. It seemed as if they were about to be sucked into a drain in the sea. ("Men at Sea" 109)

Cebuanos may respond to such passages with recognition of regional pride and good memories. Filipinos who are non-Cebuano readers will react likewise. English readers in the West are likely to experience these passages as more realistic, ethnographic with literary descriptions showing "local color." Although the load of cultural information in such passages may need to be reduced for English readers who have less knowledge of the Philippines than would locals on the whole, the tone and style of these stories translate with relative ease into English.

As for those who might read the translation of Men at Sea and Other Stories, I envisaged a multicultural and sophisticated audience of English readers who read narratives by foreigners and translations of cross-cultural, multicultural literary works. This audience might include teachers and students in English, world literature, and perhaps, comparative literature departments in universities across the globe. Such an educated audience of critical readers would have highly developed aesthetic standards for literature and would likely be open to potentially different, even subversive, points of view. The following is my translation of a key passage in the title story.

"You are a businessman, one of the rich, the most prominent and the famous. You were able to build a huge church and perform many charitable acts. The nation did not experience any calamity: fire, volcanic eruptions, floods, typhoons, earthquakes, where your name didn't make the news. You are a philanthropist. Charitable. Generous. But if your feelings of generosity towards your fellowmen are in any way true, then why do your workers go on strike, why do they cease working and bring to court their complaints and appeals? Why does this happen when you're religious? Moreover, if you've squandered money on those who have not sweated for you, how much more for those workers and employees who are the lifeblood of your business; they don't beg but only seek for justice, what's fair and commensurate to their labor? That's what I believe," he screamed, "that your faith is a fantasy and God is an illusion!" (Reyes, "Men at Sea" 107-108)

But to make this text available to a wider readership, I also imagined a set of readers with a middling knowledge of aesthetic criteria but inquisitive to know more about Cebu and its culture. Although most English readers are aware, to some degree, of the challenges and limitations facing Filipinos, few have information about the specific challenges facing Cebuanos regarding their own history and 
culture. I expected that those who read the translation would respond to a man's struggle for self-determination and recognize in the stories the belief in the aspirations and equality of all humans, the ability of people to change and grow, the love for one's native land, the need to respect others and the value of unity against an aggressor and the importance of education and family. I envisioned I was translating for educated, curious readers who would distinguish and identify with basic human values and engage with-even enjoy_- "defamiliarizing" elements and themes in the stories:

"We're not moving," the sacristan said, when he noticed that their vessel had stopped.

"We've been pooled," the drunk's companion said.

The man looked around. The sea was calm. The silence was deafening. The priest looked up to the heavens. The blue that met his gaze was gloomy. The skies were quiet.

"What can we do?" There was some irritation in the priest's voice.

"There's nothing we can do," he replied.

"It's because of you, you don't believe in God," the drunk mocked. (Reyes, "Men at Sea" 108)

I translated the political notes of the original stories so that the audience may comprehend the forces at play and participate vicariously in the dialogue.

I was in the hills when Martial Law was declared and shook the entire archipelago. This was the period when the nightmarish battle between the peasants and the soldiers began. The soldiers were possessed and lost respect for the rules of conduct as protectors of the civilian citizens. Their rampage missed no one. They killed whoever they believed was a rebel or supporting rebels or a parent or child of the rebels in the mountains. (Reyes, "God Is with You" 139)

I used a literary register hybridized with colloquial expressions that would challenge the power structures of language and culture as do many stories in the literary traditions in English.

"I did not expect that would happen to him, Maning," Mimi said after she learned the course of Paninugon's life. "But it isn't too late, Ning. You must let him understand ... Convince him ... that the gun should not be used in settling differences."

"Mimi, he has no differences to settle. He's done collecting." ("God Is with You" 141) 
I surmised that an English language audience in the West who would read the translation would be similar to Reyes's audience in some aspects and differ greatly in others. English readers would experience the culture of the stories as foreign rather than native. Although a country like America participated directly in Philippine history as a colonial power for the first half of the twentieth century, relatively few Americans alive today have been to Cebu. Notwithstanding the difference in audience, the stories offer the experience of participating in two cultures at the same time and have the potential to challenge the expectations of English readers.

Men at Sea and Other Stories presents every reader with a certain level of cultural or linguistic dislocation. Cebuanos read about and participate in their own culture through their own language. As they read in English, they translate back into their own language and culture and participate in the narrative form from an interior perspective.

Native English speakers would likely experience the translational effect of reading the foreign stories in their own language although I made an effort to gauge the degree of defamiliarization the imagined readers would accept. Sentence structures, word choice, and culture-bound concepts usually required active pushing of the text to Cebuano. I was aware that such interpretation ran the risk of sharpening edges, revealing conflicts and identifying subversive aims of the text.

Translating the stories appealed to my sense of aesthetics and necessity, because it helped revise the stereotypes of Filipinos and society, re-imagining history and events from a local perspective and raised questions that I felt needed to be considered-beyond the boundaries of the language in which it was written-by anyone who read it in English.

Conversations with Reyes brought to light the differences in our intended audience and effects as well as the similarities in our goals. This comparison helped me to distinguish more clearly for whom and for what purpose I was translating and marked the practice for my translation approach. A comparison of Reyes's and my intended audiences and effects relating to the ideological, social and political contexts complicated as well as clarified my understanding of the influences that affect a translator's decisions. Comments by readers also established the idea that readers-of whatever group-prefer language that encourages immediate and emotional participation in the construction of meaning. Gremer Chan Reyes was in a position to raise questions for the Cebuanos from within Cebuano society and modify the way others perceived Cebuanos. I am in a position to let other people of another culture see the similarity in the types of questions and perceptual revisions proposed in both cultures. Reyes aims to cause a difference in perception and behavior; I attempt to offer an experience that might act to alter foreign perceptions and behavior.

The questions I specifically considered as I translated the work were the following: (1) What audience will be reading this translation?; (2) Is my goal to challenge or accommodate the reader?; (3) What is the reader's attitude towards the translation 
and the cultural milieu it conveys? I imagined an audience compatible with the audience evoked in the original text.

Realistically, translation cannot duplicate the original given the differences not only in the languages and cultures but also in the perspectives of the author, translator, editor and readers. Even so, while translating Men at Sea and Other Stories, I attempted to recreate the original and convey its effects to the imagined audience. Because the original challenged its readers, I sought to produce a similar effect on my readers even if such an endeavor might turn them away. Within this theoretical paradigm, I maintained the slant of the text towards the source and its expectations to whatever degree necessary to produce a text that would hopefully find a place within the audience's sensibilities. 


\section{Works Cited}

Friedrich, Hugo. "On the Art of Translation." The Craft of Translation. Eds. Rainer Schulte and John Biguenet. Chicago: U of Chicago P, 1989. 11-16. Print.

Nossack, Hans Erich. "Translating and Being Translated." Theories of Translation: An Anthology of Essays from Dryden to Derrida. Eds. Rainer Schulte and John Biguenet. Chicago: U of Chicago P, 1992. 228-238. Print.

Rabassa, Gregory. "No Two Snowflakes Are Alike: Translation as a Metaphor." The Craft of Translation. Eds. Rainer Schulte and John Biguenet. Chicago: U of Chicago P, 1989. 1-12. Print.

Reyes, Gremer Chan. Men at Sea and Other Stories. Trans. Hope Sabanpan-Yu. Manila: National Commission for Culture and the Arts, 2008. Print.

---. "God Is With You." In Men at Sea and Other Stories. Trans. Hope Sabanpan-Yu. Manila: National Commission for Culture and the Arts, 2008. 136-142. Print.

Reyes, Gremer. Personal interview. 15 Aug. 2007.

Said, Edward. "Embargoed Literature." Between Languages and Cultures: Translation and Cross-Cultural Texts. Eds. Anuradha Dingwaney and Carol Maier. Pittsburgh: U of Pittsburgh P, 1995. 97-102. Print.

Venuti, Lawrence. The Scandals of Translation: Towards an Ethics of Difference. New York: Routledge, 1998. Print.

-.--. The Translator's Invisibility: A History of Translation. New York: Routledge, 1995. 